\title{
SCIENCE AS A TOOL FOR SOCIAL DEVELOPMENT
}

\author{
Venelin Terziev ${ }^{1}$
}

\begin{abstract}
Defining social efficiency and social technology is the core element of assessment methods and models, taking into account a wide range of objective and subjective factors. The assessment methods of social programmes (projects) efficiency are related to the social system's orientation towards social protection and social services of the population and the use of the process approach and the transition to programme-target methods, outlining the main issues and mechanisms for social services and tasks for assessment, determining the basic requirements for efficiency assessment of social programming and the various stages. Considering all these matters, the research offers social programming efficiency assessment model based on "organizational efficiency" approach that covers a number of certain elements: system for resources acquisition, choice of goals, assessment of the impact on the external environment, choice of strategy, following the "what if" principle and the priorities of social activity, arising from the dynamic changes in social environment. Special emphasis is put on the differentiated effect on higher education institutions, depending on the field in which universities carry out teaching and research activities, as well as on the peculiarities of the university business model in the changing environment for development of the higher education institutions.
\end{abstract}

Keywords: Social economy, social development,higher education, science, WoS

JEL Codes: O00, O20, I20, I21, P41

Citation : Terziev, V. (2020). Science as a Tool for Social Development. Review of Socio-Economic Perspectives, Vol 5(3), 117-134.

Article Type: Research Article

Application Date: 17.06.2020 \& Admission Date: 21.08 .2020 DOI: $10.19275 / \mathrm{RSEP} 091$

${ }^{1}$ Full Member of the Russian Academy of Natural History, Professor, Eng., D.Sc. (National Security), D.Sc. (Economics), D.Sc. (Social Activities), Ph.D.

Georgi Rakovski Military Academy, Sofia, Bulgaria University of Rousse, Rousse, Bulgaria

Kaneff University Hospital, Rousse, Bulgaria

Russian Academy of Natural History, Moscow, Russia ORCHID ID: 0000-0003-1115-8877

E-mail: terziev@skmat.com 


\section{Introduction}

Over the last years a lot has been said and recorded about "measuring" science, about its quality and criteria for determining its importance and value, i.e. determining its social efficiency. It is an interesting initiative both from a professional and research point of view. The process includes at least two parties: those who create science and those who evaluate it or, to be more precise, who use it. It is highly probable that the attitude of the parties towards the result will differ. In order not to make it seem too primitive and consumerist, we should consider it as a process that is too complicated, both for its reporting and assessment. Historically, the benefits of various scientific discoveries came much later, even after the death of their creators. This presents researchers of this process with a number of complex tasks that are difficult to define, measure and analyze.

Taking into account both the historical factors and the strong dynamics of our current social development, we should look for an appropriate assessment form, as well as a way to reflect this scientific and research process in an appropriate and best possible way. Such process cannot be separated or defined independently, becase it has become integrated into our existence and its accomplishments have become part of our lives.

\section{Measuring science as a way to indicate its importance}

The challenges of seeking answers to questions in terms of their usefulness, efficiency and effectiveness are related to a definite and accurate knowledge of these processes and their impact on the entire social process in which they take place, or, to be more precise, are part of it.

The impact of science on our development is a process that itself does not need to be proven, because its results are obvious to all.

Perceiving science as something abstract and incomprehensible would rather harm the process of its understanding and evaluating.

Numerous state and public institutions, Ministry of education and science of Bulgaria being one of them, are devoted to this task as part of their obligations. By developing and implementing different models and techniques in this directions there always will be support and opposition. However, in no way should this frighten, offend or discourage any of the parties. Achieving maximum justice is already a strong motivation to keep on going in the direction of objectifying the essential processes related to the scientific and research activities. Moreover, over lifelong existence it has been proven that the progress is related to scientific breakthroughs that are part of human experience.

Very often people perceive things quite pragmatically and are satisfied with the explanation that their present state is acceptable enough. The changes are rather unwanted or frightening because we associate them with ourselves. The academic community is quite conservative in its pointviews and is perceived as self-sufficient. This acceptable way may be relatively good for a certain period of time, but it is by no means acceptable and progressive for the development of these processes.

The term 'process' is complicated enough in the sense we use it, because on the one hand, it is continuous and has a number of characteristic features, complexity and even 
contradictions. It should be considered, defined and analyzed by all its participants, but mostly by those who will benefit from it, i.e. the people. Other way it will be just a pseudoscience that will bring satisfaction to a man himself without being useful to others. You will agree that the main benefit in this direction is the applicability of everything that scientists and researchers do. Historically, this has been repeated many times over the years, and in many cases scientific discoveries have been accepted and valued much later. Accepting or denying a certain scientific activity demands its understanding and approval by the society, which is not always an easy and achievable task from any point of view and sometimes impossible for a scientist.

Usually, scientific discoveries, researches or scientific projects are published in specialized publications that are available to a limited number of users who are engaged in this activity or these publications have limited access which in most cases is paid. This additionally complicates the process of their approval. Due to the need of scientific research to be published in databases with reviewed content, i.e. those that contain scientific information of high value and are peer-reviewed, they have become publications with closed or limited access to this information. This is understandable, considering the effort and hard work of respective teams or specific researchers to get feedback and be assessed in an appropriate and acceptable manner.

On the other hand, the scientists` work should reach larger number of people, since it is them who will potentially benefit from scientific achievements. For this reason, the scientists and researchers have no other choice but to constantly present their thesis statements, projects and discoveries on various forums in order to reach the consumer through different online information channels. This explanation sounds pretty simplistic, but it is relatively true. Sometimes one scientific research is presented, promoted and shown at a number of scientific conferences, round tables, symposia and exhibitions, which makes its validation rather a complicated and continuous process. This is especially true for social sciences. The resistance of the scientific community in such cases is very strong, because the search for non-traditional approaches in the validation of research violates the generally accepted slowliness of the process. This "irritates" the scientific community, which is quite introverted and even rigid in its understanding of the promotion of scientific works.

In our opinion, almost all ways of presenting scientific work are acceptable, providing that they ensure satisfactory results and reliable and true feedback and useful information. The relationship between authors (creators) and users needs to be more than just warm and sincere in order to identify omissions, drawbacks or imperfections in a sufficiently accurate and correct manner.

The amendments to the Academic Staff Development Act and the Regulations of its implementation in Bulgaria are aimed at finding answers to these questions, by creating a system of criteria that is measurable for the respective field of higher education and professional field. This system is managed by the National centre for information and documentation at the Ministry of education and science. Whether the quantitative measures embedded in this model can provide the required quality coverage is difficult to say and the answer would rather be no. Nevertheless, this system creates a certain order and visibility of the results, but it is difficult to talk about objectivity. Especially considering that different assessment and acceptability systems and different requirements 
take place at different times. Meeting certain up-to-date criteria sometimes leads to the inability of some scientists to provide adequate information, an additional difficulty being the information on paper from older periods, which can not be ignored or denied.

This does not diminish the efforts made in this direction to introduce uniform requirements for habilitation period to obtain academic positions "Associate Professor" and "Professor", as well as academic degree "Doctor" and "Doctor of Science".

Scientific works are divided in compliance with certain professional fields and several main areas are of particular importance. These include articles and reports published in scientific journals, peer-reviewed and indexed in world-known scientific databases; articles and reports published in non-peer-reviewed journals with scientific review or published in edited collective volumes; citations in monographs and collective volumes with scientific review; citations or reviews in non-peer-reviewed journals with scientific review; supervision of a student who has successfully defended their $\mathrm{PhD}$ dissertation; published university or school textbook, etc. Scientific works published in Web of Science and Scopus databases of peer-reviewed literature are of particular value. The requirements for such publications are high and the assessment of the published works is excellent. Naturally, the assessment is a matter of perception of the scientific work by the relevant evaluating (registering) body as one of the main criteria in determining the quality of the scientific activity of the individual and the institution as a whole.

All this is directly connected to various rating systems that take into account certain articles in certain publications and rank the institution according to these indicators, including citations to these scientific reports, articles or communications. Such method seems quite acceptable and adequate as an assessment technique, but the result does not always match the reality. The scientific community of Bulgaria regularly performs such assessment and at the end of each year it presents the results of the previous one. The assessment period is not chosen by chance. The indexing of the relevant publications in the two main databases is a long period, in some cases lasting more than a year. Sometimes there is a chance that part of the publishing activity of some scientists is not correctly and accurately reported. Some universities owe their progress to one or several scientists who have become a team and have established themselves in the scientific community and are therefore free to publish their works in such publications. This to some extent distorts the presented information and leads to quantitative accumulations that do not correspond to the overall assessment of the institution. In some cases, if we exclude these few scientists from the relevant higher education institution or scientific organization, the obtained data will be insignificant.

The "detachment" of research from social development in general is also a major and important issue. The questions we should ask ourselves are: what is this for? When and how will it be useful to us? Will it be useful to us at all? We should exclude purely theoretical developments, which themselves have a different meaning and necessity.

In recent years, the Ministry of education and science in connection with the Implementation of the national policy related to regular monitoring and assessment of research activities (State Gazette, issue 54 dated 29/06/2018) performs an Assessment of the research activities carried out by universities and research organizations and the Research fund. 
Assessment is made on the basis of individual cards of each institution that contain: objective information received from international databases and verified by the assessed organizations and universities; financial statement for the funds spent on research projects, under agreements with industrial manufacturers, etc. and those reflecting the exploitation of scientific results, as well as data from the national register of $\mathrm{PhD}$ students and doctors of science who has successfully defended their dissertation during the year.

The biggest share in the overall assessment based on the system of criteria and indicators belongs to the Bulgarian academy of sciences (BAS), which objectively reflects the real situation. We should take into account the main purpose and activity of the institution itself, which provides an answer to its defined, leading and dominant position. Regarding the other leading institutions: St. Kliment Ohridski Sofia University, Medical University of Sofia, University of Chemical Technology and Metallurgy of Sofia and Technical University of Sofia together with BAS, they determine almost $2 / 3$ of the total contribution to the overall assessment. The scientific research activity is mainly concentrated in the capital in the largest universities. This practically defines Sofia as a primary and most important centre of all areas of this assessment. Given the uneven territory distribution of the assessed institutions, caused by various reasons, the historical development is also significant. Outside the capital, there are several other research centres with a defined contribution to the overall assessment, located in the cities of Plovdiv, Varna, Ruse, Stara Zagora and Burgas. In fact, even the largest universities outside the capital are located in these cities. The overall assessment lacks a considerable contribution of one of the largest Bulgarian universities - University of national and world economy of Sofia.

The research defines separate scientific areas using criteria and indicators and the same is done in terms of distribution of scientific publications to the respective scientific field by Scopus and Web of Science databases. These databases distribute scientific works based on criteria and indicators that do not always correspond to our assessment system, thus the information is incompatible. This can sometimes distort or change the ranking in scientific fields. In most cases the distribution of scientific works is determined by the journal or the publications of the scientific conference in which they are included. It does not always reflect the essential standpoints of scientific work. However, such change does not affect the overall assessment of the higher education institution. Thus, the ranking by scientific fields includes higher education institutions that do not perform such scientific research in these fields. It is possible for scientists who perform certain scientific activity to conduct a research in other or several scientific areas. This complements and provides more information on the areas of interest of the scientists and researchers of the particular organization.

Quantitative indicators for different scientific areas are quite different in absolute values, thus their direct comparison is impossible and in most cases inaccurate and even incorrect.

For instance, some universities are still on top of the rankings even though their key areas of research and education differ from the specific area by which they are ranked. Generally speaking, we can conclude that financial resources are being invested in these activities, this way supporting and encouraging them. Detailed analysis helps establish that one or two prominent scientists specialized in the specific area can drastically change the overall results, which to some extent distorts the assessment in the relevant scientific area. Excluding the data from this overall assessment radically changes the ranking of 
institutions. An interesting detail is that leading scientists in certain areas form over $65 \%$ of the overall results for the institution, sometimes even reaching $90 \%$. This raises the question of whether these institutions could "claim" scientific capacity in this area or whether these exceptions should be presented separately and not be included in the overall assessment.

The relatively poor performance of higher education institutions of economic studies is rather worrying. Only the University of National and World Economy of Sofia is in 7th position after institutions such as the Higher education institution of telecommunications and posts of Sofia, Vasil Levski National Military University of Veliko Tarnovo and Angel Kanchev University of Ruse (Terziev, 2019, pp.347-349; Terziev, 2019a, pp. 263 266).

General tendency in the development of research is based on certain quantitative measures (Fig. 1). We should accept it under certain conditions taking into account the Bulgarian peculiarities and the respective results of the previous years.

Figure 1: Tendency in the research development

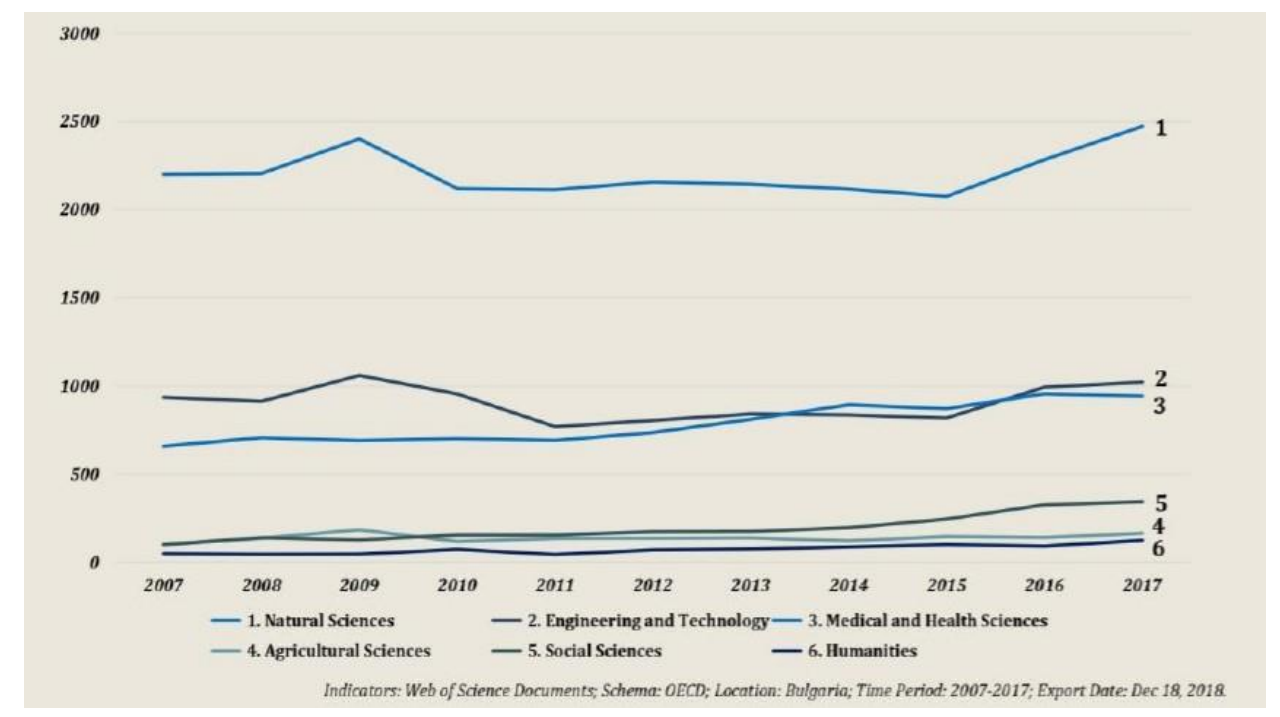

Celia Luterbacher from Switzerland expressed an interesting opinion that the international scientific community is guided by one ruthless principle "I publish, therefore I exist". According to her, we pay too much attention to the quantitative results that only take into account number of publications and citations. The authorities of Switzerland prepare a reform aimed to initiate some changes in this direction. "In the last years the quantitative results more often prevail over the qualitative ones, contributing to lower motivation among scientists, not to mention that this approach will eventually reduce the quality of scientific research. All this should involve a change in the national strategy, which takes into account the various disciplinary and institutional requirements, by applying differentiated assessment practices". 
While evaluating the current scientific capacity of Bulgaria, the authors of the research report some difficulties in collecting data, the reason being related to incomplete information about publishing activity and citation in the databases used and especially that related to the Bulgarian academy of sciences and the Academy of agricultural sciences. For objectivity of the information and assessment of the respective citation contribution in 2018 the authors used the period from 1985 to 2018. For this purpose, the quotation coefficient in the respective formula is adjusted from 0.5 to 0.05 , which also changes the role of publications in the overall assessment, as well as does not allow the comparison of the results from the previous year.

The results of scientific activity monitoring performed by higher education institutions show that the main scientific organizations are concentrated in the capital, which is completely logical, considering that the main scientific infrastructure is also situated there. Higher education institutions engaged in scientific activities in Bulgaria include: Bulgarian academy of sciences, which is the undisputed leader, followed by St. Kliment Ohridski Sofia University, Medical University of Sofia, Technical University of Sofia and the only university outside the capital - Medical University of Plovdiv. Some other universities showing high results are the University of Chemical Technology and Metallurgy of Sofia, Paisiy Hilendarski University of Plovdiv, Agricultural Academy, Dr. Paraskev Stoyanov Medical University of Varna, Thracian University of Stara Zagora and Neofit Rilski Southwestern University of Blagoevgrad.

It is noteworthy that out of total of 52 higher education institutions in the country only 11 meet the acceptable criteria for intensive and qualitative scientific activity, and 19 have a critically low level of their activity.

Practically, there are two main scientific and educational centres already existing in Bulgaria, located in Sofia and Plovdiv, whereas the rest still have a lot of work to do to catch up and there is a large group of universities with really low results. New scientific centres are emerging in the cities of Varna and Stara Zagora, however Varna, Ruse and Burgas can be characterized as changing for the worse.

Interpretations of the recommendations of the Annual Report of the Ministry are quite curious. They are divided into five groups, as follows (Terziev, 2020, pp.651-656; Terziev, Lyubcheva and Solovev, 2020a, pp. 865-869):

- The assessment and monitoring of the scientific activity of 2018 shows a serious discrepancy between the achieved results and the reality, which requires a serious reconsideration of the policies for reorganization and consolidation of the scientific potential by concentrating resources in functional associations of higher education institutions and scientific organizations. For example, if activity of 4 research departments focuses on the same scientific area and they are located on the territory of one settlement, they should be reorganized by uniting around one of them, that shows the highest results, and by concentrating the largest financial resource there.

- Universities with a small number of publications in international databases report a large number of defended dissertations for academic degree "Doctor" or "Doctor of Science". This raises doubts about the quality of those works. The National assessment and accreditation agency should give significantly more 
weight to the publications visible in renowned international databases when making decisions on accreditation of master's and doctoral programmes.

- It is advisable to differentiate research universities, which are in the first group of the ranked ones, by introducing new methods for their subsidizing from the state budget and appropriate prioritization in funding through the mechanisms of the national research programmes.

- Extremely high importance in the formula for achieved results evaluating is placed on publications and patents citations. In most cases, the importance of citations is almost ten times greater than that of scientific papers, despite the coefficient used to reduce their importance twice. A large part of the publications belongs to first-rate scientific journals, assessed according to strict criteria by the respective journals /group Q1 publications/. Citation should not be neglected, especially for a smaller scientific community such as that in Bulgaria, but it should not be given such importance. The documents of the assessment agencies in the UK and France, which were presented in 2017, do not take into account the number of citations at all. OECD reports also do not recommend using citation indexes and results when evaluating scientific activity.

- Bulgarian academy of sciences, as well as the Agricultural academy institutes specializing in research predominantly, should be considered separately from the Higher education institutions, which are engaged in various activities. Medical universities are a special group in the ranking due to several factors. Above all, it is the inclusion of most of their academic staff in medical and diagnostic activities, along with teaching and research. This, in turn, leads to constant affiliation of the academic staff with both the university and the medical institution.

Figure 2: Dynamics of scientific results (number of publications in WoS) from 2008 to 2018 of some EU member states and Serbia comparing to Bulgaria.

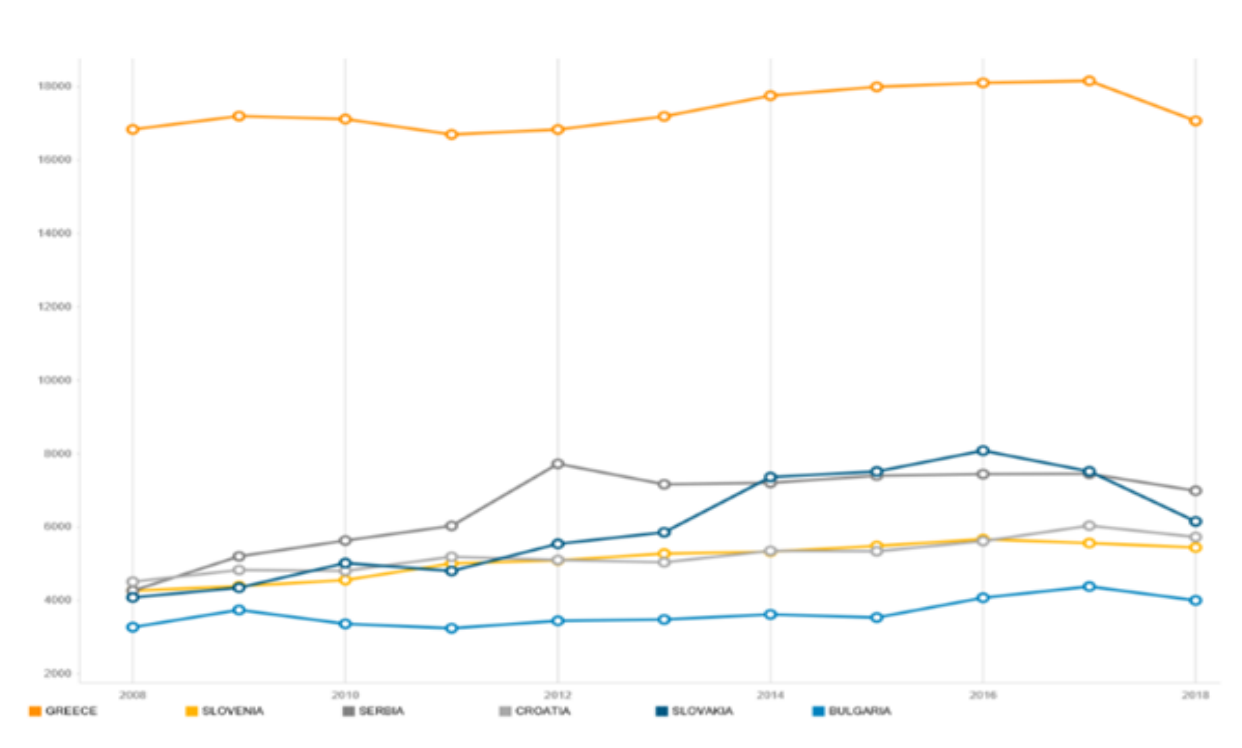


Bulgaria lags significantly behind Greece (approximately 4 times) and all other countries (from 20 to $50 \%$ ) when it comes to published scientific works, like documents in WoS. However, while the Bulgarian research staff is more or less on the same level as that of Croatia, compared to other countries it is significantly smaller - 20\% (Slovakia) and even twice (Greece, Slovenia), considering the active population in these countries (Fig. 2).

After the introduction of Regulations on the scientific activity monitoring and assessment carried out by universities and research organizations in September 2015, there is stability of the results in Bulgaria, as well as of the publications of the top $10 \%$, compared to the results of 2015. This, however, is insufficient (Fig. 3).

The coefficient of the Normalized Citation Impact from 2008 to 2018 of some EU member states and Serbia comparing to Bulgaria shows that the scientific impact of the results obtained in Bulgaria is above the world average by $15 \%$ and according to this indicator Bulgaria is significantly ahead of Croatia, Serbia and Slovakia (Fig. 4).

Figure 3: Dynamics of publications of top 10\% from 2008 to 2018 of some EU member states and Serbia comparing to Bulgaria

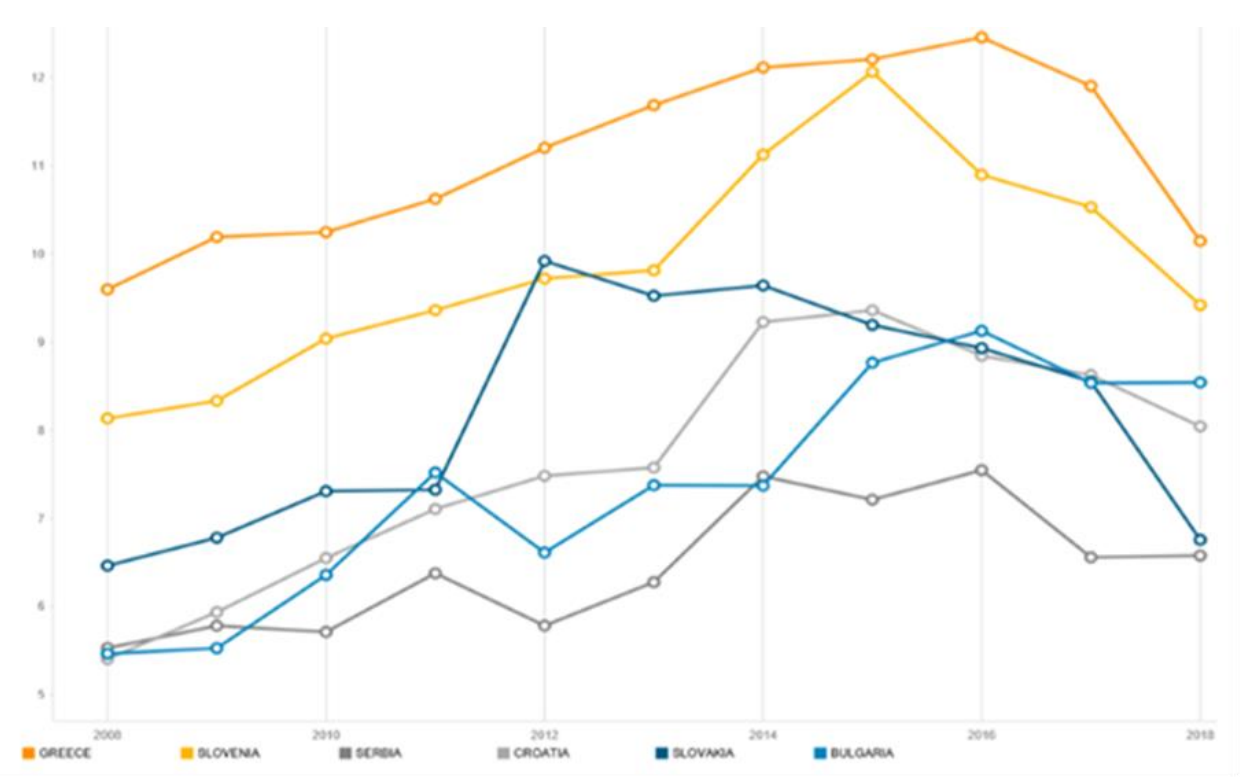


Figure 4: Dynamics of the Normalized Citation Impact from 2008 to 2018 of some EU member states and Serbia comparing to Bulgaria.

In order to be able to compare the scientific activity results carried out in comparable EU member states we can track the results of the employed scientists and researchers as $\%$ of the total active population (Table 1).

Table 1: Research staff as \% of the active population.

\begin{tabular}{|c|c|c|c|c|c|c|c|c|c|c|}
\hline $\begin{array}{l}\text { Country } \\
\text { / year }\end{array}$ & $\begin{array}{l}200 \\
8\end{array}$ & $\begin{array}{l}200 \\
9\end{array}$ & $\begin{array}{l}201 \\
0\end{array}$ & $\begin{array}{l}201 \\
1\end{array}$ & $\begin{array}{l}201 \\
2\end{array}$ & $\begin{array}{l}201 \\
3\end{array}$ & $\begin{array}{l}201 \\
4\end{array}$ & $\begin{array}{l}201 \\
5\end{array}$ & $\begin{array}{l}201 \\
6\end{array}$ & $\begin{array}{l}201 \\
7\end{array}$ \\
\hline $\begin{array}{l}\text { Europea } \\
\text { n Union }\end{array}$ & - & 1.55 & $\begin{array}{l}1.61 \\
53\end{array}$ & $\begin{array}{l}1.68 \\
84\end{array}$ & : & $\begin{array}{l}1.75 \\
64\end{array}$ & : & $\begin{array}{l}1.84 \\
53\end{array}$ & : & : \\
\hline $\begin{array}{l}\text { Euro } \\
\text { area EU } \\
19\end{array}$ & - & $\begin{array}{l}1.67 \\
36\end{array}$ & $:$ & $\begin{array}{l}1.81 \\
87\end{array}$ & : & $\begin{array}{l}1.87 \\
81\end{array}$ & : & $\begin{array}{l}1.96 \\
24\end{array}$ & : & : \\
\hline Belgium & $\begin{array}{l}1.82 \\
74\end{array}$ & $\begin{array}{l}1.86 \\
14\end{array}$ & $\begin{array}{l}1.82 \\
87\end{array}$ & $\begin{array}{l}1.96 \\
02\end{array}$ & : & $\begin{array}{l}2.04 \\
9\end{array}$ & $:$ & $\begin{array}{l}2.30 \\
8\end{array}$ & : & $:$ \\
\hline $\begin{array}{l}\text { Българи } \\
\text { я }\end{array}$ & $\begin{array}{l}0.57 \\
34\end{array}$ & $\begin{array}{l}0.63 \\
85\end{array}$ & $\begin{array}{l}0.61 \\
48\end{array}$ & $\begin{array}{l}0.63 \\
02\end{array}$ & $\begin{array}{l}0.65 \\
61\end{array}$ & $\begin{array}{l}0.67 \\
13\end{array}$ & $\begin{array}{l}0.77 \\
01\end{array}$ & $\begin{array}{l}0.90 \\
33\end{array}$ & $\begin{array}{l}1.00 \\
96\end{array}$ & : \\
\hline Czechia & $\begin{array}{l}1.44 \\
31\end{array}$ & $\begin{array}{l}1.45 \\
49\end{array}$ & $\begin{array}{l}1.50 \\
04\end{array}$ & $\begin{array}{l}1.59 \\
9\end{array}$ & $\begin{array}{l}1.69 \\
14\end{array}$ & $\begin{array}{l}1.77 \\
85\end{array}$ & 1.87 & $\begin{array}{l}1.92 \\
52\end{array}$ & $\begin{array}{l}1.91 \\
11\end{array}$ & $\begin{array}{l}2.05 \\
29\end{array}$ \\
\hline $\begin{array}{l}\text { Denmar } \\
k\end{array}$ & $\begin{array}{l}2.88 \\
46\end{array}$ & $\begin{array}{l}2.89 \\
32\end{array}$ & $\begin{array}{l}2.94 \\
43\end{array}$ & $\begin{array}{l}2.98 \\
5\end{array}$ & $\begin{array}{l}2.99 \\
29\end{array}$ & $\begin{array}{l}3.01 \\
57\end{array}$ & $\begin{array}{l}2.98 \\
08\end{array}$ & $\begin{array}{l}3.02 \\
26\end{array}$ & $\begin{array}{l}2.98 \\
2\end{array}$ & 3.13 \\
\hline
\end{tabular}


Review of Socio-Economic Perspectives

Terziev, V., pp. 117-134

Vol. 5 Issue: 3/ September 2020

\begin{tabular}{|l|l|l|l|l|l|l|l|l|l|l|}
\hline German & $:$ & 1.89 & $:$ & 2.06 & $:$ & 2.10 & $:$ & 2.22 & $:$ & $:$ \\
y & & 45 & & 53 & & 92 & & 74 & & \\
\hline Estonia & 1.43 & 1.48 & 1.52 & 1.52 & 1.55 & 1.57 & 1.61 & 1.51 & 1.40 & $:$ \\
& 6 & 71 & 41 & 35 & 09 & 01 & 91 & 21 & 33 & \\
\hline Ireland & 1.40 & 1.49 & 1.52 & 1.65 & 1.04 & 2.16 & $:$ & 2.10 & $:$ & $:$ \\
& 79 & 89 & 45 & 96 & 43 & 51 & & 59 & & \\
\hline Greece & $:$ & $:$ & $:$ & 1.44 & $:$ & 1.72 & $:$ & 2.02 & $:$ & $:$ \\
& & & & 53 & & 83 & & 66 & & \\
\hline Spain & 1.53 & 1.55 & 1.55 & 1.52 & 1.47 & 1.44 & 1.45 & 1.48 & 1.50 & $:$ \\
& 92 & 28 & 2 & 02 & 29 & 57 & 91 & 54 & 86 & \\
\hline France & $:$ & $:$ & $:$ & $:$ & $:$ & $:$ & 1.97 & $:$ & $:$ & $:$ \\
& & & & & & & 74 & & & \\
\hline Croatia & 0.92 & 0.95 & 0.98 & 0.93 & 0.92 & 0.93 & 0.88 & 0.93 & 1.03 & $:$ \\
& 74 & 98 & 66 & 74 & 5 & 89 & 59 & 07 & 17 & \\
\hline Italy & 1.45 & 1.46 & 1.43 & 1.42 & 1.46 & 1.50 & 1.48 & 1.55 & 1.72 & $:$ \\
& 04 & 33 & 87 & 97 & 71 & 08 & 22 & 86 & 44 & \\
\hline Cyprus & 0.64 & 0.65 & 0.64 & 0.66 & 0.64 & 0.70 & 0.69 & 0.70 & 0.75 & $:$ \\
& 12 & 93 & 25 & 5 & 25 & 52 & 6 & 73 & 76 & \\
\hline Latvia & 0.97 & 0.85 & 0.88 & 1.00 & 1.07 & 1.04 & 1.14 & 1.16 & 1.15 & $:$ \\
& 43 & 64 & 72 & 38 & 26 & 73 & 62 & 92 & 24 & \\
\hline Lithuani & 1.25 & 1.23 & 1.26 & 1.54 & 1.53 & 1.58 & 1.69 & 1.51 & 1.56 & $:$ \\
a & 32 & 22 & 59 & 1 & 39 & 43 & 34 & 6 & & \\
\hline Luxemb & $:$ & 2.53 & $:$ & 2.59 & $:$ & 2.28 & $:$ & 2.37 & $:$ & $:$ \\
ourg & & 26 & & 4 & & 69 & & 41 & & \\
\hline Hungary & 1.21 & 1.27 & 1.29 & 1.32 & 1.32 & 1.35 & 1.29 & 1.25 & 1.20 & $:$ \\
& 33 & 02 & 44 & 19 & 44 & 43 & 58 & 44 & 26 & \\
\hline Malta & 1.00 & 0.92 & 1.05 & 1.21 & 1.27 & 1.17 & 1.16 & 1.15 & 1.12 & $:$ \\
& 6 & 18 & 06 & 19 & 14 & 37 & 72 & 29 & & \\
\hline Netherla & 1.34 & 1.20 & 1.47 & 2.00 & 2.13 & 2.11 & 2.17 & 2.14 & 2.14 & $:$ \\
nds & 85 & 36 & 61 & 54 & 1 & 9 & 86 & 2 & 47 & \\
\hline Austria & $:$ & 2.33 & $:$ & 2.58 & $:$ & 2.74 & $:$ & 2.92 & $:$ & $:$ \\
& & 55 & & 5 & & 68 & & 13 & & \\
\hline Poland & 0.71 & 0.70 & 0.76 & 0.79 & 0.81 & 0.85 & 0.89 & 0.92 & 1.01 & $:$ \\
& 39 & 97 & 9 & 3 & 74 & 16 & 47 & 29 & 18 & \\
\hline Portugal & 1.68 & 1.71 & 1.77 & 1.83 & 1.82 & 1.90 & 1.94 & 2.08 & 2.09 & $:$ \\
& 3 & 54 & 93 & 1 & 77 & 31 & 84 & 71 & 88 & \\
\hline Romania & 0.46 & 0.44 & 0.43 & 0.48 & 0.48 & 0.49 & 0.48 & 0.49 & 0.51 & $:$ \\
\hline
\end{tabular}


Review of Socio-Economic Perspectives

\begin{tabular}{|c|c|c|c|c|c|c|c|c|c|c|}
\hline & & 72 & 61 & 15 & 22 & 11 & 37 & 05 & 04 & \\
\hline Slovenia & $\begin{array}{l}1.59 \\
09\end{array}$ & $\begin{array}{l}1.67 \\
77\end{array}$ & $\begin{array}{l}1.76 \\
72\end{array}$ & $\begin{array}{l}2.15 \\
91\end{array}$ & $\begin{array}{l}2.10 \\
51\end{array}$ & $\begin{array}{l}2.14 \\
87\end{array}$ & $\begin{array}{l}2.12 \\
44\end{array}$ & $\begin{array}{l}2.07 \\
99\end{array}$ & $\begin{array}{l}2.03 \\
89\end{array}$ & $:$ \\
\hline Slovakia & $\begin{array}{l}0.88 \\
25\end{array}$ & $\begin{array}{l}0.94 \\
73\end{array}$ & $\begin{array}{l}1.04 \\
33\end{array}$ & $\begin{array}{l}1.07 \\
18\end{array}$ & $\begin{array}{l}1.07 \\
16\end{array}$ & $\begin{array}{l}1.02 \\
93\end{array}$ & $\begin{array}{l}1.06 \\
48\end{array}$ & $\begin{array}{l}1.05 \\
74\end{array}$ & $\begin{array}{l}1.21 \\
45\end{array}$ & : \\
\hline Finland & $\begin{array}{l}2.97 \\
08\end{array}$ & $\begin{array}{l}3.00 \\
59\end{array}$ & $\begin{array}{l}3.03 \\
64\end{array}$ & $\begin{array}{l}3.06 \\
47\end{array}$ & $\begin{array}{l}3.00 \\
99\end{array}$ & $\begin{array}{l}3.01 \\
08\end{array}$ & $\begin{array}{l}2.95 \\
4\end{array}$ & $\begin{array}{l}2.90 \\
53\end{array}$ & $\begin{array}{l}2.76 \\
81\end{array}$ & $:$ \\
\hline Sweden & : & $\begin{array}{l}2.42 \\
15\end{array}$ & $:$ & $\begin{array}{l}2.57 \\
11\end{array}$ & : & $\begin{array}{l}2.69 \\
81\end{array}$ & : & $\begin{array}{l}2.74 \\
82\end{array}$ & : & : \\
\hline $\begin{array}{l}\text { United } \\
\text { Kingdo } \\
\text { m }\end{array}$ & : & $\begin{array}{l}1.65 \\
5\end{array}$ & $\begin{array}{l}1.70 \\
64\end{array}$ & $\begin{array}{l}1.82 \\
84\end{array}$ & $\begin{array}{l}1.86 \\
28\end{array}$ & $\begin{array}{l}1.94 \\
76\end{array}$ & $\begin{array}{l}2.04 \\
93\end{array}$ & $\begin{array}{l}2.11 \\
17\end{array}$ & $\begin{array}{l}2.17 \\
44\end{array}$ & : \\
\hline Iceland & $\begin{array}{l}3.26 \\
09\end{array}$ & $\begin{array}{l}2.97 \\
15\end{array}$ & $:$ & $\begin{array}{l}2.80 \\
23\end{array}$ & : & $\begin{array}{l}2.80 \\
29\end{array}$ & $:$ & $\begin{array}{l}3.18 \\
56\end{array}$ & $\begin{array}{l}3.27 \\
26\end{array}$ & 3.28 \\
\hline Norway & $\begin{array}{l}2.48 \\
34\end{array}$ & $\begin{array}{l}2.54 \\
77\end{array}$ & $\begin{array}{l}2.53 \\
28\end{array}$ & $\begin{array}{l}2.54 \\
39\end{array}$ & $\begin{array}{l}2.55 \\
35\end{array}$ & $\begin{array}{l}2.61 \\
22\end{array}$ & $\begin{array}{l}2.73 \\
46\end{array}$ & $\begin{array}{l}2.87 \\
59\end{array}$ & $\begin{array}{l}3.01 \\
85\end{array}$ & $:$ \\
\hline $\begin{array}{l}\text { Switzerl } \\
\text { and }\end{array}$ & $:$ & $:$ & $:$ & $:$ & $\begin{array}{l}2.65 \\
86\end{array}$ & $:$ & $:$ & $\begin{array}{l}2.70 \\
28\end{array}$ & $:$ & $:$ \\
\hline $\begin{array}{l}\text { Montene } \\
\text { gro }\end{array}$ & : & $:$ & $:$ & $\begin{array}{l}0.88 \\
55\end{array}$ & : & $\begin{array}{l}0.89 \\
56\end{array}$ & $\begin{array}{l}0.89 \\
62\end{array}$ & $\begin{array}{l}0.89 \\
24\end{array}$ & $\begin{array}{l}0.82 \\
17\end{array}$ & : \\
\hline $\begin{array}{l}\text { FYR } \\
\text { Macedon } \\
\text { ia }\end{array}$ & $\begin{array}{l}0.30 \\
11\end{array}$ & $\begin{array}{l}0.26 \\
2\end{array}$ & $\begin{array}{l}0.28 \\
44\end{array}$ & $\begin{array}{l}0.23 \\
87\end{array}$ & $\begin{array}{l}0.29 \\
66\end{array}$ & : & : & $\begin{array}{l}0.45 \\
31\end{array}$ & $\begin{array}{l}0.46 \\
56\end{array}$ & : \\
\hline Turkey & $\begin{array}{l}0.54 \\
63\end{array}$ & $\begin{array}{l}0.56 \\
87\end{array}$ & $\begin{array}{l}0.59 \\
7\end{array}$ & $\begin{array}{l}0.63 \\
75\end{array}$ & $\begin{array}{l}0.69 \\
9\end{array}$ & $\begin{array}{l}0.71 \\
94\end{array}$ & $\begin{array}{l}0.76 \\
08\end{array}$ & $\begin{array}{l}0.77 \\
6\end{array}$ & $\begin{array}{l}0.81 \\
39\end{array}$ & $\begin{array}{l}0.86 \\
53\end{array}$ \\
\hline Russia & $\begin{array}{l}1.00 \\
56\end{array}$ & $\begin{array}{l}0.98 \\
08\end{array}$ & $\begin{array}{l}0.97 \\
58\end{array}$ & $\begin{array}{l}0.97 \\
03\end{array}$ & $\begin{array}{l}0.96 \\
1\end{array}$ & $:$ & $:$ & $:$ & $:$ & $:$ \\
\hline Serbia & : & : & : & : & $:$ & : & 0.72 & $\begin{array}{l}: 0.7 \\
8\end{array}$ & 0.77 & 0.74 \\
\hline $\begin{array}{l}\text { South } \\
\text { Korea }\end{array}$ & $\begin{array}{l}1.79 \\
17\end{array}$ & $\begin{array}{l}1.91 \\
37\end{array}$ & $\begin{array}{l}2.02 \\
09\end{array}$ & $\begin{array}{l}2.11 \\
61\end{array}$ & $:$ & $:$ & $:$ & : & $:$ & $:$ \\
\hline
\end{tabular}

Bulgaria is a modest innovator and remains the least performing country in the EU-28 due to its structural underfunding, complicated procedures to access project funding, fragmented funding in various fields, weak science-education-business connection and lack of strategic focus on interventions in this area. 
The innovation index of Bulgaria is not only considerably lower than average for the EU (33\%), but also decreases rapidly in absolute terms and relative share compared to the EU average from 2011 to 2013 (from 44\% to 33\%). It is noteworthy that these poor results are significantly affected by the low funding of research and development activities in the public sector as a percentage of GDP, weak innovation activity of small and medium-sized enterprises and by the strong orientation of the research system in Bulgaria to basic science (Table 2). The commercialization of the results is a major weakness of the Bulgarian research system. There are only very limited frameworks to support collaboration between public research organizations, universities and the private sector. Exchange and support systems are not sufficiently developed to facilitate the transfer of knowledge, the creation of university spin-off companies and to attract (venture) capital. Public policies do not promote long-term sustainable partnerships between all parties involved in innovation. The analysis of the results outlines a serious reason for this weakness, especially in terms of cooperation between research organizations and business in Bulgaria. The Bulgarian chamber of commerce and industry publishes official data showing that Bulgarian companies are not prepared to implement innovations independently (only 23\% of entrepreneurs have expressed such readiness) or to commission universities and research organizations to develop new products. This lack of collaboration and mutual trust between research organizations and enterprises together with negative experience in commercialization of the research results of scientific organizations and businesses is one of the main reasons for the country's low innovative activity (ranking last in the EU). Not surprisingly, patent activity is also very low. Therefore, special efforts are needed to bring together the interests of research organizations and businesses, as well as to actively support and encourage their collaboration. The analysis of the state of research in Bulgaria carried out by the Ministry of education and science outlines the weaknesses as to the quality of services provided by parties of the public research sector, as well as the potential for development of research and innovation. The main problem in this area is weak cooperation with business, in particular:

- Lack of coordinated actions related to research and innovation;

- Lack of modern scientific and innovative infrastructure; Fragmented institutional environment;

- Low share of funding on a competitive basis and low overall funding rate;

- Unfavourable age profile;

- Insufficient interaction between research organizations and companies. 
Table 2: R\&D expenditure by field of science and sectors in 2018 (thousand levs)

\begin{tabular}{|l|l|l|l|l|l|}
\hline Field of & Total & \multicolumn{3}{|l|}{ Sectors: } \\
\cline { 2 - 6 } science & Entrepreneurs & Public & $\begin{array}{l}\text { Higher } \\
\text { education }\end{array}$ & $\begin{array}{l}\text { Non-profit } \\
\text { organizations }\end{array}$ \\
\hline Total & 828904 & 596083 & 182841 & 45141 & 4839 \\
\hline $\begin{array}{l}\text { Natural } \\
\text { sciences }\end{array}$ & 116407 & 16802 & 85262 & 13236 & 1107 \\
\hline $\begin{array}{l}\text { Technical } \\
\text { sciences }\end{array}$ & 478098 & 436116 & 28592 & 12611 & 779 \\
\hline $\begin{array}{l}\text { Medical and } \\
\text { health } \\
\text { sciences }\end{array}$ & 144079 & 132211 & 3061 & 8736 & 71 \\
\hline $\begin{array}{l}\text { Agricultural } \\
\text { and } \\
\text { veterinary } \\
\text { sciences }\end{array}$ & 36062 & 4378 & 30462 & 1046 & 176 \\
\hline $\begin{array}{l}\text { Social } \\
\text { sciences }\end{array}$ & 24671 & 5071 & 12482 & 4818 & 2300 \\
\hline $\begin{array}{l}\text { Humanities } \\
\text { and arts }\end{array}$ & 29587 & 1505 & 22982 & 4694 & 406 \\
\hline
\end{tabular}

Note: Research and development (R\&D)

There are also some strengths supporting market-oriented change. These include good traditions in the natural sciences, preserved scientific schools and high publishing activity in some areas relevant to emerging technologies (physics, chemistry, materials science, biochemistry and molecular biology, medicine, pharmaceutical and engineering sciences), cultural diversity combined with specific national identity, strong orientation of researchers towards international cooperation, positive attitude of the society towards education and science.

However, these strengths shall be compliant with the objectives and priority areas of the National strategy for implementing the innovative potential of the research system. We need to work on adaptability and sustainability of the potential through a stronger emphasis on market signals and ways to attract private investors.

New and well-equipped research infrastructures are important elements of ecosystems in the field of research and development and innovation. The analysis identifies the following negative trends in the state of research infrastructure: 
- obsolete facilities and inefficient exploitation of the existing ones;

- lack of an advanced approach to administrative and financial management of the existing infrastructure in basic organizations;

- lack of professionals and qualified employees to work with the facilities and their users;

- lack of coordination and complementarity of the available modern facilities within one organization or between different organizations;

- lack of equipment concentration and, in some cases, a highly individual approach and duplication of equipment.

Prepared diagnostic review of the research infrastructure and equipment in Bulgaria confirms the lack of sufficient modern infrastructures that meet modern requirements for research and innovation. Out of a total 161 research infrastructures in Bulgaria, 12 are of European importance (7\%), 84 are of national importance (52\%) and 65 are of regional importance $(40 \%)$. About $30 \%$ of all infrastructure has been in operation for the last 15 years or more, and $70 \%$ of infrastructure has attracted between 25,000 and 100,000 euros per year for the last five years.

The lack of sufficient funding in the field of research and innovation (Table 3), especially in infrastructures outside Sofia, leads to the impossibility to develop potential for smart specialization in Bulgaria. Generally, the diagnostic review identifies the need to support the best-developed infrastructures, with potential in the thematic areas at national and regional level.

Table 3: R\&D expenditure by statistical regions and sectors in 2018 (thousand levs)

\begin{tabular}{|c|c|c|c|c|c|}
\hline \multirow{2}{*}{$\begin{array}{ll}\text { Field } & \text { of } \\
\text { science } & \end{array}$} & \multirow[t]{2}{*}{ Total } & \multicolumn{4}{|l|}{ Sectors: } \\
\hline & & Entrepreneurs & Public & $\begin{array}{l}\text { Higher } \\
\text { education }\end{array}$ & $\begin{array}{l}\text { Non-profit } \\
\text { organizations }\end{array}$ \\
\hline Total & $\begin{array}{l}828 \\
904\end{array}$ & 596083 & 182841 & 45141 & 4839 \\
\hline $\begin{array}{l}\text { North and } \\
\text { Southeast } \\
\text { Bulgaria }\end{array}$ & $\begin{array}{l}155 \\
936\end{array}$ & 119110 & 25133 & 11333 & 360 \\
\hline $\begin{array}{l}\text { Northwestern } \\
\text { region }\end{array}$ & 37437 & 30325 & 6892 & - & - \\
\hline $\begin{array}{l}\text { North Central } \\
\text { region }\end{array}$ & 26612 & 24328 & 365 & 1919 & - \\
\hline $\begin{array}{l}\text { Northeastern } \\
\text { region }\end{array}$ & 49750 & 30837 & 13697 & - & - \\
\hline
\end{tabular}


Review of Socio-Economic Perspectives

Terziev, V., pp. 117-134

Vol. 5 Issue: 3/ September 2020

\begin{tabular}{|l|l|l|l|l|l|}
\hline $\begin{array}{l}\text { Southeastern } \\
\text { region }\end{array}$ & 42137 & 33620 & 4179 & - & - \\
\hline $\begin{array}{l}\text { Southwest } \\
\text { and South } \\
\begin{array}{l}\text { Central } \\
\text { Bulgaria }\end{array}\end{array}$ & $\begin{array}{l}672 \\
968\end{array}$ & 476973 & 157708 & 33808 & 4479 \\
\hline $\begin{array}{l}\text { Southwestern } \\
\text { region }\end{array}$ & 603 & 424479 & 148320 & 28021 & 3033 \\
\hline $\begin{array}{l}\text { South Central } \\
\text { region }\end{array}$ & 69115 & 52494 & 9388 & 5787 & 1446 \\
\hline
\end{tabular}

Note: Research and development (R\&D)

The improvement of the infrastructure will significantly expand the opportunities of Bulgarian scientists to conduct high-quality research at a global level and will support the development of high-tech industry in Bulgaria. The problems identified above can be solved by increasing the participation of Bulgarian scientific organizations in joint European initiatives and infrastructures. In view of the insufficient resources, and as a way to adapt the research capacity to the needs described above, its main objectives include:

- Support for the research development policies described in the National strategy for research development until 2030 by addressing the priorities and reflecting the agenda for the creation of scientific infrastructures;

- Identification of the priorities for sustainable development of scientific infrastructures until 2023, by upgrading the Diagnostic review of scientific Infrastructures and equipment, which revealed gaps, but also the potential for smart specialization in Bulgaria through policies in the field of research and innovation.

\section{Conclusions}

Due to the extreme complexity of monitoring and assessing the strategic and long-term consequences of social activities within the broad social approach in determining social effectiveness, we shall consider the social effectiveness of accomplished activities in detail. This means the highest efficiency in solving a specific social problem. The assessment of the effectiveness of social processes in this case is reduced to the task of optimizing the social management activity in the process of solving specific social programmes through a programme approach. Therefore, this requires, more than ever, the definition of criteria for social processes effectiveness based on which to implement appropriate assessment methods and technologies.

The introduction of such assessment systems would raise number of questions and critical remarks. The first one is who will make this qualitative assessment and in what way. Currently, the accepted method is the h-index, which takes into account the respective number of references to a particular article and the other, time indicator, used to determine this quantity for the last 5 years. Different systems would show different results because 
information databases differ in their completeness and accessibility. Specific systems can be used for various areas of higher education and professional fields, which will provide relatively true and accurate information. Some will say that it is better to have some system than not to have any and they will be absolutely right. The lack of a system of measurable criteria has led to a number of paradoxical differences in assessment levels. I cannot say whether this determines the quality of a candidate for a particular academic position, but it is to some extent a confirmation of the expertise of the relative committee. In this case it is a scientific jury that would evaluate and rank the candidates. Usually the competition in our country is held with only one candidate. For some professional fields this is simply the lack of other candidates, but sometimes it is also impossible to hold the relevant position due to a number of objective circumstances. These circumstances are related to difficulties in the development of the academic staff in recent decades, unattractiveness of the field or lack of research funding. Sometimes the location of the respective higher education institution is unacceptable for the candidates. In other cases, only candidates from the inner circles are tolerated, despite the fact that the number of available candidates from the outside would be large and good enough. In this case, the work of experts would be much more difficult and the competition - greater. More than one candidate would be a potential choice. Another issue of correctness is the subsequent selection by the scientific and faculty council. In many cases, they are quite diverse in terms of their priorities and interests, thus persuasion becomes challenging and is not always associated with objective judgment or right choice. In this case, the question is whether they are competent enough to change the end result, despite the fact that this is within their powers.

And if we consider this as a secondary problem, then the process of searching and finding suitable candidates in this very limited labour market of scientists and researchers becomes a vicious circle. It is not a secret that some universities have been providing source of income for entire families for years. There is nothing wrong with that, as the craft is passed down from generation to generation, but to what extent do the opportunities of our children match our life and scientific interests?! They hardly do, but it is an easy enough option, aided by academic autonomy. Such a study would provide frightening results of closeness and interconnectedness. Particularly interesting results are observed in smaller communities, as the processes there are self-regulated by this factor.

The change we are moving towards requires a certain fairness and accuracy, but we are unlikely to achieve it only by these adjustments in the legislation. It should rather be linked to changes in system management. Very often we talk about mandate, creativity, strategies, etc., and it is generally related to shaping the attitudes of general meetings in a certain way, which in some cases correlates with the norms of morality and law. However, the procedures are legal and not very moral. There is a lot of evidence in this direction all the time.

Not always the democratic rules allow choosing the most capable and competent candidates and sometimes they do not even allow some scientists to express themselves for a number of reasons. This is a general issue mostly applicable to the academic community. The personalities here are numerous and are specialized in different fields. Consolidation is sometimes at the expense of a choice that is related to other circumstances rather than the qualities of the individual. The change in this direction is possible if this choice includes competition based on the most objective criteria. 
In the current development of society, science cannot develop on its own, and the existence of science alone is impossible and unthinkable. This requires work in wider teams and cooperation in various areas. It also requires the development of an interdisciplinary approach and the development of scholars in different directions and fields. This does not make the person/scientist a "painkiller", but makes them far more able to meet the dynamics of the requirements of a rapidly changing environment.

Finding such a system of social criteria that would describe and value this social process to the highest extent and as failrly as possible is quite a challenging task, which requires the analysis of a large amount of information and conducting various research to allow the development of such mechanism that on the one hand, meets expectations and, on the other hand, achieves a relatively accurate and valid assessment of these processes.

\section{References}

Terziev, V. (2019). "Managing changes in the system of higher education". 23rd International Scientific Conference Knowledge in practice (13-15.12.2019), Bansko, Bulgaria, Institute of Knowledge Management, Skopje, 35, 2019, 1, pp. 347-349, ISSN 1857-923X (for eversion) ISSN 2545 - 4439 (for printed version).

Terziev, V. (2019a). “The development of education in Bulgaria”. Proceedings of SOCIOINT 20196th International Conference on Education, Social Sciences and Humanities 24-26 June 2019 - Istanbul, Turkey, International Organization Center of Academic Research, Istanbul, Turkey, 2019, pp. 263-266, ISBN: 978-605-82433-6-1.

Terziev, V. (2020). "Factors influencing education system". Economic and Social Development (Book of Proceedings), 50th International Scientific Conference on Economic and Social Development Development, 13-14 February 2020, Chelyabinsk, 2020, pp. 651-656, ISSN 1849-7535.

Terziev, V., Lyubcheva, M. § Solovev, D. (2020a). "The interaction: business- educationinvestment for development". Proceedings of INTCESS 2020-7th International Conference on Education and Social Sciences 20-22 January, 2020 - DUBAI (UAE), International Organization Center of Academic Research, Istanbul, Turkey, 2020, pp. 865-869, ISBN: 978-605-82433-8-5. 